\title{
Impact of Community Attachment and Resident's Support on Destination Sustainability: Evidence from Spiritual and Community Destination in Vietnam
}

\author{
Trong Thuy THAN ${ }^{1}$, Thi Phuong Hoa KIEU ${ }^{2}$, Thi Anh Duong PHAM ${ }^{3}$, Thi Cam Van HOANG \\ Thi Hau TRAN ${ }^{5}$, Huu Doan NGUYEN ${ }^{6}$, Trung Kien DAO ${ }^{7}$
}

Received: June 01, 2020 Revised: June 21, 2020 Accepted: July 09, 2020

\begin{abstract}
This study investigates the influence of community involvement on the destination sustainability for community destinations and spiritual destinations in Vietnam. Community involvement is measured by two constructs, which are community attachment and residents' support. A structural questionnaire consisting of 41 observation variables measured on a 5-point Likert scale was used to survey households who live in a spiritual destination in An Giang province and three community destinations in Lang Son province with the help of local tour guides and Youth Union. 168 out of 200 responses collected were valid for multivariate data analysis. The results of confirmatory factor analysis (CFA) and structural equation modeling (SEM) reveal three main findings. Firstly, community attachment has a direct effect on both perceived benefits and destination sustainability. Secondly, while residents' support has a direct effect on perceived benefits, it indirectly affects destination sustainability. Finally, community destinations have a higher level of sustainability than the spiritual destination. Based on those findings, this study proposed three suggestions for local authorities, policymakers, and residents to improve the sustainable development of their local tourism destinations, including (1) diversifying local tourism products, (2) encouraging the community participation in tourism development programs, and (3) increasing in the expected benefits in local tourism development policies.
\end{abstract}

Keywords: Destination Sustainability, Community Attachment, Resident Support, Spiritual Tourism, Community Tourism

JEL Classification Code: L83, R11, R58, Z32

${ }^{1}$ First Author. Faculty of Trade and Tourism (FCT), Industrial University of Ho Chi Minh City, Vietnam.

Email: thantrongthuydnvtours@gmail.com

${ }^{2}$ Faculty of Economics and Business, Phenikaa University, Vietnam. Email: kieuhoa1452001@gmail.com

${ }^{3}$ The Center of Quantitative Analysis, QA Global JSC, Vietnam. Email: duongpham0816@gmail.com

${ }^{4}$ Faculty of Economics and Business, Phenikaa University, Vietnam. Email: hoangcamvan6@gmail.com

${ }^{5}$ Faculty of Economics and Business, Phenikaa University, Vietnam. Email: tranthihau1503001@gmail.com

${ }^{6}$ Faculty of Economics and Business, Phenikaa University, Vietnam. Email: nhdoanaaa@gmail.com

${ }^{7}$ Corresponding Author. Faculty of Economics and Business, Phenikaa University, Vietnam [Postal Address: To Huu Street, Yen Nghia Ward, Ha Dong District, Hanoi, 12116, Vietnam]

Email: kien.daotrung@phenikaa-uni.edu.vn

(c) Copyright: The Author(s)

This is an Open Access article distributed under the terms of the Creative Commons Attribution Non-Commercial License (http://Creativecommons.org/licenses/by-nc/4.0/) which permits unrestricted noncommercial use, distribution, and reproduction in any medium, provided the original work is properly cited.

\section{Introduction}

Tourism plays an important role in the economic system of Vietnam and the world. It is estimated that the sector of travel and tourism contributed $10.4 \%$ to the global GDP and $10 \%$ to the global total employment (WTTC, 2019). In Vietnam, the tourism industry contributes over $8 \%$ GDP, with total revenue of approximately 31 billion USD, and a growth of $17 \%$ in 2019 (Vietnam National Administration of Tourism, 2020). Tourism activities have improved residents' standard of living as they increase their income, create job opportunities, prompt business operators, improve infrastructure, preserve cultural value, and promote cultural exchange (Ji, Li, \& King, 2015; Methew \& Sreejesh, 2017; Wang \& Chen, 2015).

However, besides economic benefits, tourism activities also have negative effects on the environment and the 
ecosystem (Pan, Gao, Kim, Shah, Pei, \& Chiang, 2018). Tourism activities are estimated to release about 1300 million metric tons of CO2 (Peeters \& Dubois, 2010), which accounts for $5 \%$ of the global CO2 emission (IPCC, 2007) and threaten the sustainable development capacity. Therefore, it is necessary to develop proper forms of tourism toward sustainable development. Sustainable tourism destination development is a process that requires profit maximization and cost reduction, while satisfying tourists' demands related to tourism decision-making (Cottrell, Vaske, \& Roemer, 2013; López, Virto, Manzano, \& Miranda, 2018).

In Vietnam, the growth in residual income has led to high demand for tourism in recent years. It is estimated that the average growth rate of the tourism industry will remain at a 2-digit level in years to come (Vietnam National Administration of Tourism, 2020). Together with this, there is the emergence of spiritual freedom and the rehabilitation of traditional celebrations and religions, which results in the rapid growth of spiritual tourism (Than \& Le, 2018). Spiritual and community tourism is considered as one of the important keys for the development of sustainable tourism destinations.

The promotion of sustainable tourism development requires residents' supports and community cohesion toward benefitting the community (Lee, 2013; López, Virto, Manzano, \& Miranda, 2018). Supports from residents and the level of community attachment are key factors to ensure the success of sustainable destination development (López, Virto, Manzano, \& Miranda, 2018) because the participation of residents in destination development highlights the sense of responsibility and guarantee justice by suggesting actions to adapt with the environment and provide opportunities to residual development (Sebele, 2010; López, Virto, Manzano, $\&$ Miranda, 2018). Hence, the development of sustainable tourism destinations needs the involvement of residents and the creation of socio-economic and cultural advantages for the locals.

Although community attachment and residents' support play a vital role in the success of the sustainable development for tourism destinations (López, Virto, Manzano, \& Miranda, 2018; Mathew \& Sreejesh, 2017), there are few studies on this topic in Vietnam. Some recent studies focus on aspects of destination attractiveness, service responsiveness in order to attract travelers (Phan \& Dao, 2017; Than \& Le, 2018; Le $\&$ Le, 2020; Nguyen, 2020), evaluate factors that impact on intention to purchase travel services such as travel packages through internet (Dao, Tapanainen, Nguyen, Nguyen, \& Nguyen, 2017; Tapanainen, Nguyen \& Dao, 2019), industry and university collaboration (Nguyen \& Nguyen, 2020), and rarely studies destination sustainability. Thus, this research is conducted to assess the impact of community attachment, residents' support on sustainable development by the residents' perceived benefits of two potential forms of sustainable tourism - spiritual tourism and community tourism.

\section{Literature Review and Hypotheses}

\subsection{Sustainable Development for Tourism Destinations}

Sustainable tourism was initiated in the 1980 s, suggesting that tourism should be developed and sustained regionally (community) without depleting or changing the environment (Butler, 1993). UNEP and WTO (2005) define that sustainable tourism is developing tourism activities with proper balance among environmental, socio-economic, and cultural aspects to ensure long-term sustainability for tourism destinations. Tourism activities must meet tourists' needs, and simultaneously, create opportunities for future development, and protect heritages, ecosystem integrity, biodiversity, and lifesaving system (López, Virto, Manzano, \& Miranda, 2018; Pan, Gao, Kim, Shah, Pei \& Chiang, 2018). The purposes of sustainable development for tourism destinations are promoting long-term welfare for the development demand of such destinations (Lee, 2013; Nicholas, Thapa \& Ko, 2009), and benefits for residents (Lee, 2013; Yu, Chancellor, \& Cole, 2011).

Traditionally, sustainable development for tourism destination is assessed on three aspects: (1) Socio-economics, (2) culture, and (3) environment (Mathew \& Sreejesh, 2017; UNEP \& WTO, 2005). In particular:

Socio-economic sustainability mentions the welfare promotion for social members at the destination, equal development opportunities for everyone, and the justice guarantee for the development opportunities of community members (Mathew \& Sreejesh, 2018; UNEP\& WTO 2005). Aspects of socio-economic sustainability are reflected by the development of local business systems, the improvement of households' income, income stability and employment, empowerment in community management, improved infrastructure system, and social issue handling (Mathew \& Sreejesh, 2017).

Cultural sustainability mentions the residents' awareness of indigenously cultural heritage and value protection, the recognition of and respect for the cultural preservation, and the development of the community. Aspects of cultural sustainability are reflected by the preservation of heritage, intangible cultural values of the community, the maintenance and reconstruction of traditional cultural values (Mathew \& Sreejesh, 2017; UNEP \& WTO, 2005).

Environmental sustainability mentions the development of tourism without creating negative impacts on habitats, biodiversity, and ecosystems. The main aspects of environmental sustainability assessment include habitat protection, emission management, and reduction, natural 
Trong Thuy THAN, Thi Phuong Hoa KIEU, Thi Anh Duong PHAM, Thi Cam Van HOANG, Thi Hau TRAN, Huu Doan NGUYEN,

landscape protection, and local environmental protection activities (Mathew \& Sreejesh, 2017; UNEP\& WTO 2005).

\subsection{Community Attachment}

Community attachment is described as the cohesion of residents with the destination, including the impact, the meaning, the feeling, intangible values, and the connection of residents with the destination (Lee, 2013; Nicholas, Thapa \& Ko, 2009). The community attachment refers to the dependence on the destination, the characteristics of the destination, and the emotional attachment of the residents with the destination (Lee \& Shen, 2013; López, Virto, Manzano \& Miranda, 2018). Community attachment relates to residents' perception of benefits from tourism destinations (López, Virto, Manzano \& Miranda, 2018). Some research argues that residents who have a sense of attachment with the destination see more socio-economic benefits from such a destination than those who have less attachment (Lee, 2013). Community attachment of residents may prompt them to act more to protect the sustainable development of the destinations because of the advantages that they receive from the destinations. Hence, this research proposes the following hypotheses:

H1: Community attachment has a positive effect on the perceived benefits of households at tourism destinations.

H2: Community attachment has a positive effect on sustainable destination development.

\subsection{Residents' Support}

Residents' support is the participation in supporting ideas, and programs for local tourism development. Residents' support has favorable impacts on the economic benefits of the destinations (Liu, Qu, Huang, Chen, Yue, Zhao \& Liang, 2014; López, Virto, Manzano \& Miranda, 2018). It helps distribute benefits more equally, solve one of the main problems in sustainable development. In another word, residents' support on tourism development programs is an important factor indicating the success of sustainable tourism development (López, Virto, Manzano \& Miranda, 2018). Benefits from tourism programs can promote the assistance efforts of stakeholders. The promises on the success possibility and benefit received can encourage residents to support sustainable tourism development at the destinations more actively thanks to their expectations of socio-economic and cultural benefits brought about. Thus, this research hypothesizes:

H3: Residents' support has a positive effect on the perceived benefit of households at tourism destinations.
H4: Residents'support has a positive effect on sustainable destination development.

\subsection{Perceived Benefits}

Perceived benefits are the subjective perception of residents at the tourism destinations, which relates to their expectations (about socio-economics and culture) coming from the increasing number of tourists visiting their destinations (López, Virto, Manzano \& Miranda, 2018). Perceived benefits are conceptualized with two aspects: (1) socio-economic benefits and (2) cultural benefits (Gursoy \& Rutherford, 2004; Sinclair-Maragh, Gursoy \& Vieregge, 2015). The socio-economic aspect relates to job opportunities, infrastructure improvement, new business establishment, and local economy welfare contribution (Dyer, Gursoy, Sharma \& Carter, 2007; Gursoy \& Rutherford, 2004; López, Virto, Manzano \& Miranda, 2018). The other aspects refer to the local culture preservation, cultural activity, and the local - tourist culture exchange development (Gursoy \& Rutherford, 2004; Stronza \& Gordillo, 2008; López, Virto, Manzano \& Miranda, 2018). The rise in perceived benefits from the increase in the number of visitors may encourage the community to put more effort into sustainable tourism development programs. Residents who benefit from tourism activities tend to support tourism development at a higher level, compared with those receiving fewer benefits from these activities (Jurowski \& Gursoy, 2004; López, Virto, Manzano \& Miranda, 2018). Therefore, this research hypothesizes:

H5: Perceived benefits of residents have a positive effect on destination sustainability.

We also considered the difference in the level of sustainable development between two forms of tourism surveyed through two control variables about the types of destinations. Spiritual tourism destination was coded as "1", while community tourism destination was coded as " 0 ". As spiritual tourism is highly seasonal in nature so we assumed that the spiritual tourism destination has a lower level of sustainable development than the community tourism destination. The hypothesis is:

H6: The spiritual tourism destination has a lower level of sustainable development than the community tourism destination.

\section{Methodology}

\subsection{Measures}

Items for each construct in the model were developed based on an extensive literature review and several previous 
H2

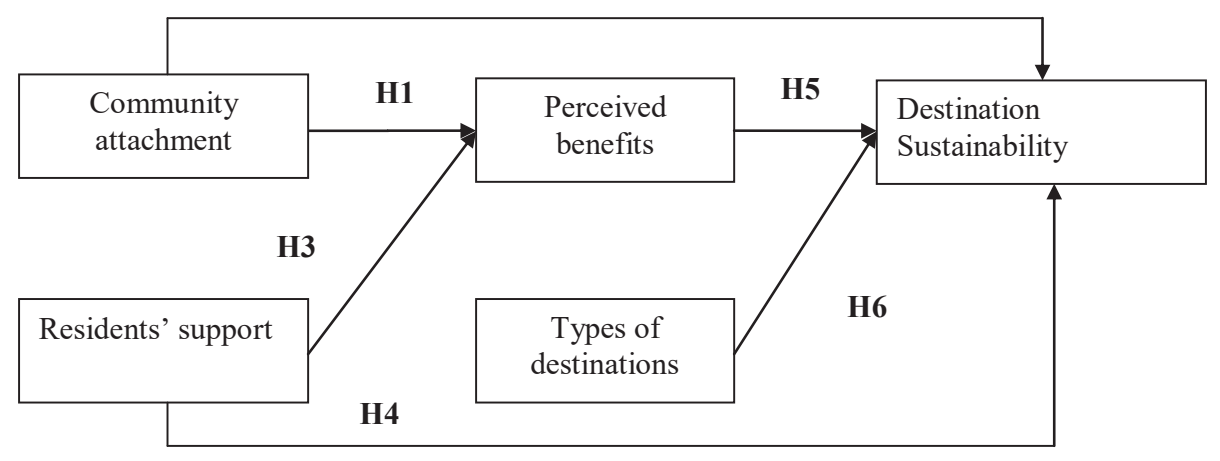

Figure 1: Proposed research model

studies (Lee, 2013; López, Virto, Manzano, \& Miranda, 2018; Mathew \& Sreejesh, 2017; Sinclair-Maragh, Gursoy, \& Vieregge, 2015; UNEP \& WTO, 2005; Wang \& Chen, 2015). Specifically, the community attachment scale was measured by 10 items adapted from Lee (2013) and López, Virto, Manzano, and Miranda (2018). The residents' support scale was measured by four items based upon from López, Virto, Manzano, and Miranda (2018). The perceived benefits scale is a multidimensional with two dimensions: socioeconomic benefits and cultural benefits. The socio-economic benefits scale was measured by five items, while the cultural benefits scale was measured by four items, referring to $\mathrm{Ji}$, Li and King (2015), López, Virto, Manzano, and Miranda (2018), Sinclair-Maragh, Gursoy, and Vieregge, (2015), and Wang and Chen (2015). The destination sustainability construct is also a multidimensional scale with three main dimensions: socio-economic sustainability (10 items), cultural sustainability (4 items) and environmental sustainability (5 items) adapted from UNEP and WTO (2005); Mathew and Sreejesh (2017), and López, Virto, Manzano, and Miranda (2018). The items were translated from English to Vietnamese and using the back-translation method to ensure the translating process did not change their original meanings. After translation, the questionnaire items were then assessed in bilateral discussions with 5 behavioral and tourism development researchers. The selected items for the official survey are presented in table 1 . All items were assessed on the 5-point Likert scale ranging from strongly disagree (1) to strongly agree (5) (see Table 1).

\subsection{Samples and Data Collection}

Data was collected at a spiritual destination in An Giang province (south) and a community destination at Lang Son province (north) using a convenience sampling method. We survey a representative of each household in the selected areas from $11 / 2019$ to $01 / 2020$. The minimum sample size should be 150 to ensure the data reliability for factor analysis. The survey in An Giang was conducted at the spiritual destination of Via Ba-Nui Sam with the support from DANUVI service tourist Co. LTD. Local tour guides were trained about the purposes of the survey and how to conduct it before interviewing households living $10 \mathrm{~km}$ surrounding the tourist area. The tour guides did a field survey with the households and their network. In Lang Son province, three destinations surveyed are in Bac Son district, including Mo Mam stream, Hu cave (Chien Thang commune), and Quynh Son community-based cultural tourism village (Quynh Son commune). We interviewed households there with help from the Youth Union of the commune. Leaders of local affiliates (villages) gave the questionnaires to the representatives of the households in local Union activities. Finally, there were 168 valid responses out of 200 responses collected, the valid response rate of $84 \%$. The sample demographics are described in Table 2 .

\subsection{Data Analysis Method}

We used multivariate data analysis to analyze and test the proposed hypotheses. As items were adapted from previous studies, the confirmatory factor analysis (CFA) is used to test validity and overall model fit of collected data. Criteria for CFA are: Chi-square/df $<3$ (Hair, Black, Babin $\&$ Anderson, 2010), CFI, TLI, IFI $<0.85$ and RMSEA $<$ 0.08 (Kline, 2011; Hooper, Coughlan \& Mullen, 2008). If factor loadings are greater than 0.5 , the construct achieves convergent validity (Hair, Black, Babin \& Anderson, 2010). The discriminant validity of the constructs was examined by the $95 \%$ confidence interval of the correlation coefficients. If the $95 \%$ confidence interval does not contain value 1 , there is discriminant validity between the constructs. If composite reliability coefficients (CR) and Cronbach's alphas over 0.7, and average variance extracted (AVE) over 30\% indicates, 
Table 1: Items

\begin{tabular}{|c|c|c|}
\hline Codes & Items/Statement & References \\
\hline \multicolumn{3}{|c|}{ Community attachment } \\
\hline COM1 & We feel that living in the region have a great meaning & \multirow{10}{*}{$\begin{array}{l}\text { Lee (2013); } \\
\text { López, Virto, } \\
\text { Manzano, and } \\
\text { Miranda (2018) }\end{array}$} \\
\hline COM2 & We feel attached to this destination. & \\
\hline COM3 & We feel that we truly belong to this destination. & \\
\hline COM4 & We have many friends/ family members here. & \\
\hline COM5 & We feel that we like living here than in other places. & \\
\hline COM6 & We think that the living infrastructure is quite good & \\
\hline COM7 & We prefer living here than other places & \\
\hline COM8 & We like living in this community (with those around) than other communities & \\
\hline COM9 & Our family determined to live here & \\
\hline COM10 & We have a sense that this place is part of our lives & \\
\hline \multicolumn{3}{|c|}{ Residents' support } \\
\hline SUP1 & We support the local development based on the ideas of sustainable tourism development & \multirow{4}{*}{$\begin{array}{l}\text { López, Virto, } \\
\text { Manzano, and } \\
\text { Miranda (2018) }\end{array}$} \\
\hline SUP2 & We participated in actions related to local sustainable tourism development. & \\
\hline SUP3 & We frequently join in cultural tourism activities with tourists. & \\
\hline SUP4 & We are eager to advertise our place anywhere. & \\
\hline \multicolumn{3}{|c|}{ Perceived benefits } \\
\hline \multicolumn{3}{|c|}{ Socio-economic benefits } \\
\hline BES1 & There are more job opportunities at our place. & \multirow{5}{*}{$\begin{array}{l}\text { Ji, Li and King } \\
\text { (2015); López, } \\
\text { Virto, Manzano, } \\
\text { and Miranda } \\
\text { (2018) }\end{array}$} \\
\hline BES2 & Local products are consumed more easily thanks to tourism & \\
\hline BES3 & Tourists coming here are willing to spend much money on their tourism activities. & \\
\hline BES4 & Business activities and small enterprises develop better thanks to tourism. & \\
\hline BES5 & The conditions of the public facilities have been improved thanks to tourism. & \\
\hline \multicolumn{3}{|c|}{ Cultural benefits } \\
\hline BCU1 & Our locals want to preserve our cultural specificity. & \multirow{4}{*}{$\begin{array}{l}\text { Sinclair-Maragh, } \\
\text { Gursoy \& } \\
\text { Vieregge(2015); } \\
\text { Wang \& Chen } \\
\text { (2015) }\end{array}$} \\
\hline BCU2 & Our locals focus on promoting cultural activities for tourism. & \\
\hline BCU3 & We find an increase in the number of cultural exchange activities with tourists. & \\
\hline BCU4 & Our residents feel a higher desire of protecting cultural values and beliefs thanks to tourism. & \\
\hline \multicolumn{3}{|c|}{ Destination Sustainability } \\
\hline \multicolumn{3}{|c|}{ Socio-economic sustainability } \\
\hline ESS1 & Local businesses have grown better thanks to tourism. & \multirow{10}{*}{$\begin{array}{l}\text { UNEP \& WTO } \\
\text { (2005); Mathew } \\
\text { \& Sreejesh } \\
\text { (2017); López, } \\
\text { Virto, Manzano, } \\
\text { and Miranda } \\
\text { (2018) }\end{array}$} \\
\hline ESS2 & Residents have higher income thanks to tourism & \\
\hline ESS3 & There are more local job opportunities thanks to tourism. & \\
\hline ESS4 & Your family income is more stable and more sustainable thanks to tourism. & \\
\hline ESS5 & $\begin{array}{l}\text { The locality has combined tourism development and community economic development } \\
\text { well. }\end{array}$ & \\
\hline ESS6 & Local tourism activities have brought many benefits to the disadvantages & \\
\hline ESS7 & The locality has developed positive social improvement programs and plans. & \\
\hline ESS8 & People are better empowered to participate in planning local development policies. & \\
\hline ESS9 & The infrastructure system has been improved. & \\
\hline ESS10 & Our local community has paid more attention to social issues. & \\
\hline \multicolumn{3}{|c|}{ Cultural sustainability } \\
\hline CS1 & The preservation and management of local heritages have been better. & \multirow{4}{*}{$\begin{array}{l}\text { UNEP \& WTO } \\
\text { (2005); Mathew } \\
\text { \& Sreejesh } \\
\text { (2017) }\end{array}$} \\
\hline CS2 & The general cultural values of the community have been well protected. & \\
\hline CS3 & Tourism activities are developed following with local conditions. & \\
\hline CS4 & Our traditional cultural values have been restored and well protected. & \\
\hline \multicolumn{3}{|c|}{ Environmental sustainability } \\
\hline ERS1 & Local habitat is well protected & \multirow{4}{*}{$\begin{array}{l}\text { UNEP \& WTO } \\
\text { (2005); Mathew } \\
\text { \& Sreejesh } \\
\text { (2017) }\end{array}$} \\
\hline ERS2 & Environmental pollution has been controlled and reduced & \\
\hline ERS3 & The local natural landscape is well protected & \\
\hline ERS4 & Local Environmental protection activities gained attention & \\
\hline
\end{tabular}


Table 2: Sample profiles

\begin{tabular}{|l|l|c|c|}
\hline \multicolumn{2}{|c|}{ Characteristics } & Number of households & Percentages (\%) \\
\hline \multirow{4}{*}{ Provinces } & An Giang & 77 & 45.8 \\
\cline { 2 - 4 } & Lạng Son & 91 & 54.2 \\
\hline \multirow{5}{*}{ Occupations of respondents } & Officers & 15 & 8.9 \\
\cline { 2 - 4 } & Office staffs & 11 & 6.5 \\
\cline { 2 - 4 } & Businessmen/businesswomen & 31 & 18.5 \\
\cline { 2 - 4 } & Farmers & 51 & 30.4 \\
\cline { 2 - 4 } & Others & 60 & 35.7 \\
\hline \multirow{5}{*}{ Academic levels } & Primary school & 20 & 11.9 \\
\cline { 2 - 4 } & Lower secondary school & 42 & 25.0 \\
\cline { 2 - 4 } & Upper secondary school & 54 & 32.1 \\
\cline { 2 - 4 } & Professional secondary school & 9 & 5.4 \\
\cline { 2 - 4 } & Community college & 10 & 6.0 \\
\cline { 2 - 4 } & Undergraduate & 33 & 19.6 \\
\hline \multirow{4}{*}{\begin{tabular}{l} 
Household average income (million \\
\cline { 2 - 4 }
\end{tabular}} & $<10$ & 73 & 43.5 \\
\cline { 2 - 4 } & $10-20$ & 69 & 81.1 \\
\cline { 2 - 4 } & $20-30$ & 14 & 7.1 \\
\cline { 2 - 4 } & $>30$ & 12 & 8.3 \\
\hline
\end{tabular}

the constructs have adequate reliability (Nguyen \& Nguyen, 2009). Finally, the proposed hypotheses were tested by the structural equation model (SEM) at a significant level of $5 \%$.

\section{Results}

\subsection{Reliability, Validity and Model Fit}

CFA indicated that the model was fit with actual data: Chi-square $/ \mathrm{df}=1.814<3, \mathrm{CFI}=0.873, \mathrm{TLI}=0.855, \mathrm{IFI}=$ $0.876>0.85$ and RMSEA $=0.070<0.08$. After deleting unsatisfied items, all factor loadings exceed 0.5 , ensuring convergent validity. The $95 \%$ confidence interval did not include value 1 , indicating discriminant validity between the constructs (see Table 3).

Additionally, all CR were greater than 0.7. AVE of each factor was over $30 \%$, and Cronbach's alphas of unidimensional scale exceed 0.7. Hence, we concluded the internal consistency of each first-order construct was satisfied and all scales (unidimensional and multidimensional) achieved adequate reliability and validity (see Table 4).

\subsection{SEM and Hypothesis Test}

A structural equation model was used to test the hypotheses. The results indicated that the structural model fits the actual data: Chi-square $/ \mathrm{df}=1.857<3, \mathrm{CFI}=0.858$,
$\mathrm{IFI}=0.861$ all were greater than 0.85 , and $\mathrm{RMSEA}=0.072$ was smaller than 0.08 . Figure 2 details of estimation results of relationship (see Figure 2).

The results presented that community attachment has a positive impact on residents' perceived benefits at community and spiritual destinations ( $\mathrm{p}$-value $<0.05$ ). Community attachment and perceived benefits directly affect sustainable destination development ( $p$-value $<0.05$ ). However, there is no evidence of the direct influence of the residents' support on sustainable destination development ( $p$-value $>0.05$ ), yet it has an indirect effect only. The type of destination also affects its sustainable development. Particularly, community tourism tends to have a higher level of sustainable development than the spiritual one $(\beta=-0.20<$ 0 , p-value $<0.05$ ). Therefore, we accept hypotheses H1, H2, $\mathrm{H} 3, \mathrm{H} 5, \mathrm{H} 6$, and reject $\mathrm{H} 4$.

\section{Discussion and Implications}

This research was conducted to assess the impacts of community attachment and residents' support on sustainable development at the community and spiritual tourism destinations. We record a strong effect of community attachment on perceived benefits and sustainable destination development. This indicates that increasing the cohesion of residents with the local community can promote the sustainable development of the destination. The high level 
Table 3: Result of model fit assessment

\begin{tabular}{|c|c|c|c|c|}
\hline Variable & Number of items & Mean & S.D & Range of factor loadings \\
\hline \multicolumn{5}{|l|}{ Unidimensional scale } \\
\hline Community attachment & 10 & 3.922 & 0.677 & $0.606-0.768$ \\
\hline Residents' support & 4 & 3.968 & 0.681 & $0.774-0.826$ \\
\hline \multicolumn{5}{|l|}{ Multidimensional scale } \\
\hline \multicolumn{5}{|l|}{ Perceived benefits } \\
\hline Socio-economic benefits & 5 & 3.913 & 0.653 & $0.703-0.767$ \\
\hline Cultural benefits & 4 & 4.065 & 0.560 & $0.552-0.689$ \\
\hline \multicolumn{5}{|l|}{ Destination sustainability } \\
\hline Socio-economic sustainability & 10 & 3.986 & 0.555 & $0.533-0.686$ \\
\hline Cultural sustainability & 4 & 3.895 & 0.677 & $0.623-0.818$ \\
\hline Environmental sustainability & 4 & 3.836 & 0.797 & $0.643-0.797$ \\
\hline
\end{tabular}

Table 4: Reliability of the instruments

\begin{tabular}{|l|c|c|c|}
\hline \multicolumn{1}{|c|}{ Variable } & Cronbach's Alphas & C.R \\
\hline Unidimensional instrument & 0.860 & 0.811 & $46.39 \%$ \\
\hline Community attachment & 0.737 & 0.780 & $64.06 \%$ \\
\hline Residents' support & - & 0.887 & $79.86 \%$ \\
\hline Multidimensional instrument & - & 0.959 & $88.86 \%$ \\
\hline Perceived benefits & \multicolumn{3}{|c|}{} \\
\hline Sustainable destination development & & & \\
\hline
\end{tabular}

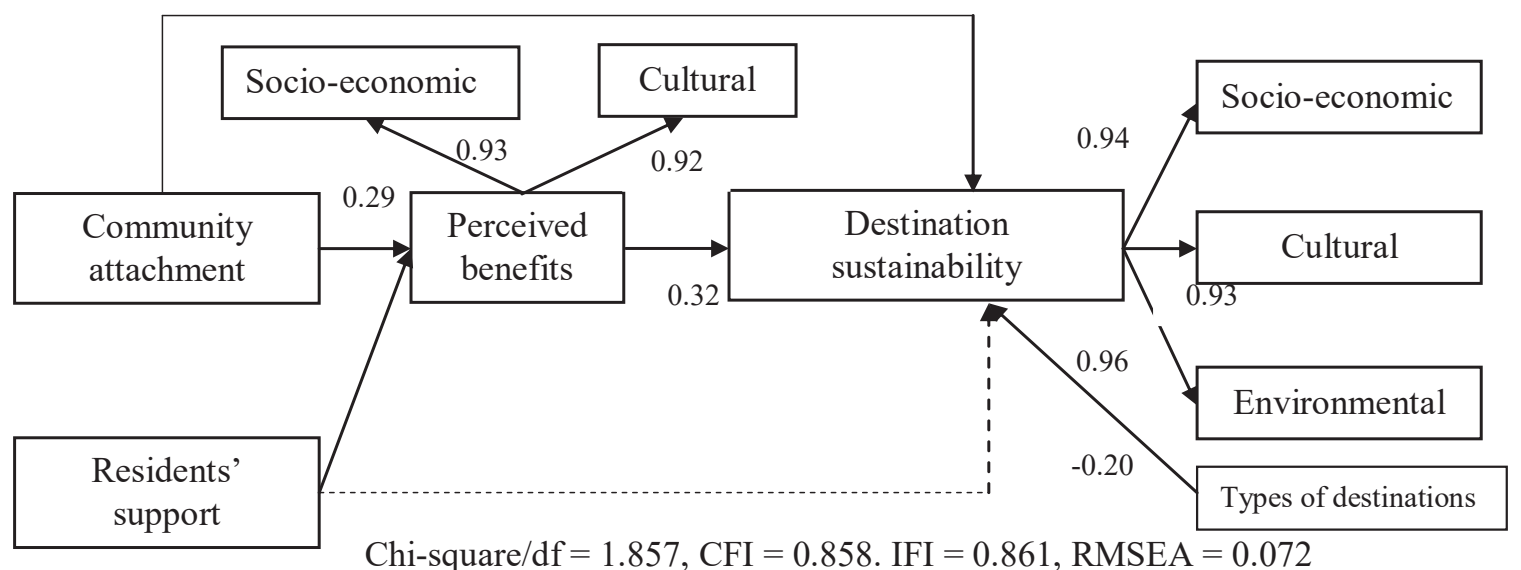

Figure 2: SEM estimated results (standardized)

\footnotetext{
Notes: $\longrightarrow$ Statistically significant $\quad------\rightarrow$ Statistically insignificant
}

Dummy variable "tourism destination": 0 = community destination, 1 = spiritual destination 
of community attachment usually links to their benefits from the destination (Lee, 2013; López, Virto, Manzano, \& Miranda, 2018). This result is consistent with some previous studies that indicated a positive effect of high-level cohesion on the improvement of sustainable destination development (Lee, 2013; Lee \& Shen, 2013; López, Virto, Manzano, \& Miranda, 2018). This implies that, to sustainably develop destinations, it is necessary to raise the sense of attachment among households and destinations. Motivations for such attachment often come from the dependence (livelihood) of households, personal traits, or their familiarity with the destinations (López, Virto, Manzano, \& Miranda, 2018).

The research also finds a significant influence on residents' support on households' perceived benefits. However, there is no evidence of a direct relationship between residents' support and sustainable development, only an indirect relationship exists. This suggests that the expectation of benefits can encourage residents to put more effort into the participation in local tourism development actions and programs, which give an implication that whether sustainable destination development policies need to involve residents' support, which often starts from benefits they will receive.

The research result also acknowledges a positive impact of perceived benefits on sustainable development. This result is quite similar to prior studies ( $\mathrm{Ji}, \mathrm{Li}, \&$ King, 2015; López, Virto, Manzano, \& Miranda, 2018; Wang \& Chen, 2013) and can be explained by the relationship between expected benefits and results. When the households at the tourism destination feel that they will gain more benefits they will tend to support sustainable destination development policies (López, Virto, Manzano, \& Miranda, 2018), which implies that to ensure the successful sustainable destination development programs, local policymakers need to focus on assuring the benefit of a community member at destinations (tourists, residents, enterprises).

We also recognize different ratings between dimensions of sustainable development. While socioeconomic sustainability has a relatively high average point (approximately 4/5), the average points for cultural and environmental sustainability are lower. This reflects the current issues of local cultural preservation and environmental pollution threats at spiritual and community tourism destination. The result also points out that community destinations have a higher level of sustainability than the spiritual destination. This can be because of the seasonal nature of spiritual destinations. Spiritual destinations usually are highly seasonal, tourism activities often focus on a particular period (festivals) each year. Meanwhile, community activities can be exploited more at various times during the years.

From the above results, we offer several implications for local authorities, policymakers, and residents at the tourism destinations to develop sustainable tourism at spiritual and community destinations: (i) promoting the community attachment by diversifying local tourism products. Developing a wide range of tourism products will increase tourist spending to ensure the socio-economic sustainability, which in turn raising community attachments by socio-economics benefits; (ii) policy planning and establishment need to involve the role of the resident community. The involvement and support of residents are the keys to the successful operation of the programs. This participation can be achieved through the mechanism of establishing representatives from self-governing groups or civil society organizations to assure the benefits of parties; (iii) development policies should aim at increasing expected benefits of stakeholders because they are motivations for involvement.

Despite the achievement of research purposes, this study has certain limitations that may provide opportunities for future investigations. First, the sample size is relatively small, which can affect the study generalization. Secondly, this study only focuses on the impact of resident involvement (community attachment, residents' support) on sustainable development, leaving the gap of responsible tourism practices at destinations. Hence, future research should increase the sample size and incorporate the role of responsible tourism practices into the research model.

\section{References}

Butler, R.W (1993). Tourism - an evolutionary perspective. In J.G. Nelson, R.W. Butler and G. Wall (Eds), Tourism and Sustainable Development: Monitoring, Planning, Managing (pp 27-44), Waterloo, Ontario: University of Waterloo.

Cottrell, S. P., Vaske, J. J., \& Roemer, J. M. (2013). 'Resident satisfaction with sustainable tourism: The case of Frankenwald Nature Park, Germany'. Tourism Management Perspectives, 8 , 42-48.

Dao, T. K., Tapanainen, T. J., Nguyen, H. T. T., Nguyen, T. H., \& Nguyen, N. D. (2017). Information Safety, Corporate Image, and Intention to Use Online Services: Evidence from Travel Industry in Vietnam. Proceedings of the 23rd Americas Conference on Information Systems, Boston, USA, August $10-12$.

Dyer, P., Gursoy, D., Sharma, B., \& Carter, J. (2007). Structural modeling of resident perceptions of tourism and associated development on the Sunshine Coast, Australia. Tourism Management, 28(2), 409-422.

Gursoy, D., \& Rutherford, D. G. (2004). Host attitudes toward tourism: An improved structural model. Annals of Tourism Research, 31(3), 495-516.

Hair, J. F., Black, W. C., Babin, B. J., \& Anderson, R. E. (2010). Multivariate data analysis ( $7^{\text {th }}$ ed.). Upper saddle River, New Jersey: Pearson Education International. 
Hooper, D., Coughlan, J., \& Mullen, M. R. (2008). Structural equation modeling: Guidelines for determining model fit. Electronic Journal of Business Research Methods, 6(1), 53-60

Ji, M., Li, M., \& King, B. (2015). The Impacts of China's new freetrade zones on Hong Kong tourism. Journal of Destination Marketing \& Management, 4(4), 203-205

Jurowski, C., \& Gursoy, D. (2004). Distance effects on residents' attitude toward tourism. Annals of Tourism Research, 31(2), 296-312.

Kline, R. B. (2011). Principles and practice of structural equation modeling (3rd ed.). New York, NY: Guilford Press

Lee, T. H. (2013). Influence analysis of community resident support for sustainable tourism development. Tourism Management, 34, $37-46$.

Lee, T. H., \& Shen, Y. L. (2013). The influence of leisure involvement and place attachment on destination loyalty: Evidence from recreationists walking their dogs in urban parks. Journal of Environmental Psychology, 33, 76-85

Le, H. B. H., \& Le, T. B. (2020). Impact of Destination Image and Satisfaction on Tourist Loyalty: Mountain Destinations in Thanh Hoa Province, Vietnam. Journal of Asian Finance, Economics, and Business, 7(4), 185-195. https://doi. org/10.13106/jafeb.2020.vol7.no4.185

Liu, J., Qu, H., Huang, D., Chen, G., Yue, X., Zhao, X., \& Liang, Z. (2014). The role of social capital in encouraging residents' pro-environmental behaviors in community-based ecotourism. Tourism Management, 41, 190-201

López, M. F. B., Virto, N. R., Manzano, J. A., \& Miranda, J. G. M. (2018). Residents' attitude as determinant of tourism sustainability: The case of Trujillo. Journal of Hospitality and Tourism Management, 35, 36-45.

Mathew, P. V., \& Sreejesh, S. (2017). Impact of responsible tourism on destination sustainability and quality of life of community in tourism destinations. Journal of Hospitality and Tourism Management, 31, 83-89.

Nguyen, D. T. \& Nguyen T. M. T. (2009). Researches of business administration. Hanoi, Vietnam: Statistical Publishing House.

Nguyen, T. Q., \& Nguyen, H. T. T. (2020). Factors Affecting Industry and University Collaboration in Education in the Hospitality Industry in Vietnam: A Business Perspective. Journal of Asian Finance, Economics and Business, 7(2), 291-300. https://doi. org/10.13106/jafeb.2020.vol7.no2.291

Nguyen, X. T. (2020). Factors That Influence the Intentions to Revisit Korea of Vietnamese Tourists. Journal of Asian Finance, Economics, and Business, 7(4), 247-258. https://doi. org/10.13106/jafeb.2020.vol7.no4.247
Nicholas, L. N., Thapa, B., \& Ko, Y. J. (2009). Residents' perfectives of a world heritage site: The Pitons Management Area, St. Lucia'. Annals of Tourism Research, 36(3), 390-412.

Pan, S. Y., Gao, M., Kim, H., Shah, K. J., Pei, S. L., \& Chiang, P. C. (2018). Advances and challenges in sustainable tourism toward a green economy. Science of the Total Environment, 635, 452469.

Peeters, P., \& Dubois, G. (2010). Tourism travel under climate change mitigation constraints. Journal of Transport Geography, 18(3), 447-457.

Phan, M.D., \& Dao, T.K. (2017). The impact of destination image and emotional value on satisfaction and visitor loyalty: A case study in Dalat city. Journal of Economics and Development, 236(1), 82-91.

Sebele, L. S. (2010). Community-based tourism ventures, benefits and challenges: Khama rhino sanctuary trust, central district, Botswana. Tourism Management, 31(1), 136-146.

Sinclair-Maragh, G., Gursoy, D., \& Vieregge, M. (2015). Residents' perceptions toward tourism development: A factor-cluster approach. Journal of Destination Marketing \& Management, 4(1), 36-45.

Stronza, A., \& Gordillo, J. (2008). Community views of ecotourism. Annals of Tourism Research, 35(2), 448-468.

IPCC (2007). Contribution of Working Group I to the Fourth Assessment Report of the Intergovernmental Panel on Climate Change. In Solomon, S., D. Qin, M. Manning, Z. Chen, M. Marquis, K.B. Averyt, M. Tignor and H.L. Miller (Eds.), IPCC Fourth Assessment Report (AR4), Cambridge, United Kingdom and New York, NY, USA: Cambridge University Press

Tapanainen, T., Nguyen, T. T. H., \& Dao, T.K. (2019). The role of corporate image and privacy concerns in adopting online travel services. The Journal of Information Systems, 28(3), 1-23.

Than, T.T., \& Le, A.T (2018), The impact of destination attractiveness on tourist satisfaction and intention to visit the spiritual destination in Vietnam, Journal of Economics and Development, 252(1), 90-100.

Vietnam National Administration of Tourism (2020), Statistics, Hanoi, Vietnam. Retrieved April 7, 2020, from <http:// vietnamtourism.gov.vn/index.php/statistic/receipts>

Yu, C. P., Chancellor, H. C., \& Cole, S. T. (2011). Measuring residents' attitudes toward sustainable tourism: A reexamination of the sustainable tourism attitude scale. Journal of Travel Research, 50(1), 57-63.

WTTC (2019). World Tourism and Travel Economic Impact 2019. London, UK: World Tourism and Travel Council.

Wang, S., \& Chen, J. S. (2015). The influence of place identity on perceived tourism impacts. Annals of Tourism Research, 52, $16-28$ 